\title{
The impact of job description and career prospect on job satisfaction: A quantitative study in Mauritius
}

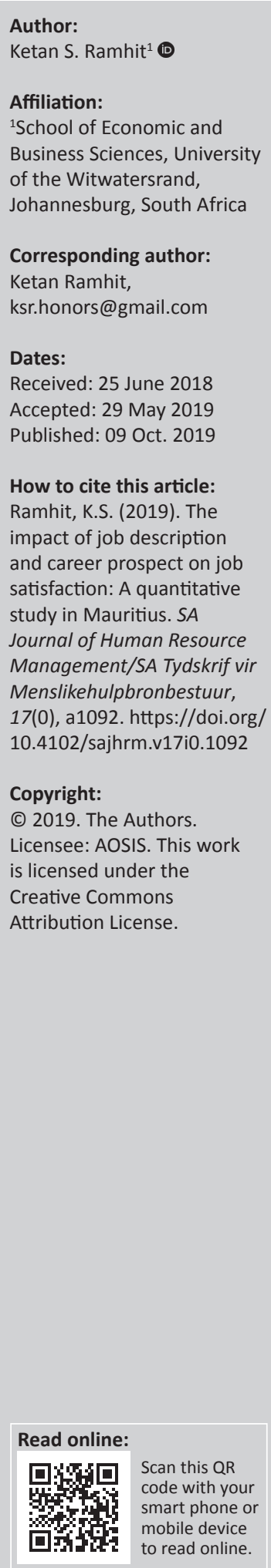

Orientation: Literature shows that job description and career prospect are connected to job satisfaction and it is seen that, in Mauritius, job description and career prospect impact job satisfaction.

Research purpose: The purpose of the study was to determine the relationship between job description, career prospect and job satisfaction in Mauritius.

Motivation for the study: It has been noticed that employees are dissatisfied when they perform duties outside their job description and also when they see that they do not have a good career prospect. Despite the existence of several researches, limited research exists in the Mauritian context. The outcome will provide significant relevance to existing knowledge.

Research approach/design and method: A quantitative approach was adopted and a survey was conducted in a multinational company in Mauritius. A sample of 132 employees was chosen.

Main findings: This research unravelled significant negative relationships between job description, career prospect and job satisfaction. The results revealed that, when duties are not well described or when duties are not in line with current responsibilities, the employees are dissatisfied. Similarly, the greater the chances that employees are not given the opportunity to get promoted, the more they are dissatisfied.

Practical/managerial implications: Human resource practitioners, managers and team leaders need to recognise that employee's moods influence the work pattern in the organisation and a clear job description and an appropriate career plan should exist.

Contribution/value-add: Literature on the relationship between job description, career prospect and job satisfaction in the context of Mauritius is almost inexistent. This study will add to existing knowledge.

Keywords: job description; career prospect; job satisfaction; multinational; Mauritius; business process outsourcing.

\section{Introduction}

\section{Orientation}

Job satisfaction has always stimulated the interest of researchers in the field of human resource because of its impact on both a company's and individual's performance. With the rising number of multinational companies, decision-makers face various challenges to improve job satisfaction (Westover, 2012). Iles and Judge (2004, p. 383) provide evidence that job satisfaction is an evaluative judgement made by people in particular situations and these situations trigger different types of behavior (Millar \& Tessar, 1989) and the observations made by Iles and Judge (2004) further consolidated the fact that the workplace predicts job satisfaction. Therefore, relative to the situations, employees will either like or dislike their jobs (Robbins \& Judge, 2013, p. 82), helping researchers to better understand the consequences of job dissatisfaction.

Statistics Mauritius (2018) reported that in the year 2018, among the unemployed people in Mauritius, $31 \%$ have quit their previous job positions because of job dissatisfaction. This number seems insignificant but cannot be neglected as it raises the questions such as why people are dissatisfied with their current or past job. Robbins and Judge (2013, p. 73) indicate that a person's feelings towards a job depend on what the latter has understood after the person has evaluated what the job is about and what responsibilities the job entails. Therefore, depending on what the 
job can give to the employee, the latter will either hold a feeling towards or hold a relationship with that particular job, and that feeling can either be positive or negative (Robbins \& Judge, 2013, p. 74).

There are various constituents forming part of a job that influences employees' feelings towards their respective job position and, according to Locke (1976), there are elements that determine how much employees are pleased with their job. Therefore, it is deduced that there are factors that make the job less pleasurable (Locke, 1976) and the attitudes of employees change when they face certain situations, which do not coincide with their expectations (Iles \& Judge, 2004). A wide range human resource management research on job satisfaction exists, yet research on job description and career prospect in Mauritius is limited.

This study gears towards two major situations faced by employees: (1) 'performing duties outside job description' and (2) 'limited career prospect'. These two variables are considered inherent because employees expect their job positions to offer them the desired indulgence (Armstrong, 2012; Robbins \& Judge, 2013), if not, they lose interest in their day-to-day tasks (Armstrong, 2006).

\section{Research purpose, research objectives and hypotheses}

This study seeks to determine the respective effects and impacts of job description and career prospect on job satisfaction.

The objective is to empirically determine whether relationships exist between job description, career prospect and job satisfaction in the Mauritian context. Job satisfaction is regarded as the outcome variable while job description and career prospect are the predictor variables. Based on literature, the following hypotheses were developed:

Hypothesis $1\left(\mathrm{H}_{1}\right)$ : Job Description will negatively impact job satisfaction in the Mauritian context.

Hypothesis $2\left(\mathrm{H}_{2}\right)$ : Career Prospect will negatively impact job satisfaction in the Mauritian context.

\section{Literature review}

\section{Definition of job satisfaction}

Job satisfaction is extensively investigated worldwide (Iles \& Judge, 2004; Lumley, Coetzee, Tladinyane, \& Ferreira, 2011) and has become a very important factor in human resource management (Waqas et al., 2014) and organisational behavior (Robbins \& Judge, 2013). For Locke (1976, p. 1297), job satisfaction is 'a pleasurable or positive emotional state resulting from the appraisal of one's job or job experiences'. Locke's (1976) definition clearly explains that individuals are mentally and emotionally affected by different experiences that particular job positions provide, influencing their opinion following evaluation and appreciation of their encounter at work (Iles \& Judge, 2004). In the same vein, Mullins (2002) argued that 'needs and expectation at work' would influence the level of job satisfaction because employees become self-concerned about what they could achieve as a reward in the workplace (Bhojak \& Shakdwipee, 2014). Robbins and Judge (2013) explain that job satisfaction describes how an employee feels about the job, that is, if a person holds positive attitudes toward a job, the latter is satisfied (Armstrong, 2006). Conversely, if a person is not pleased with the job, then the latter is dissatisfied (Armstrong, 2006). Job satisfaction can thus be defined as 'the attitudes and feelings people have about their work' (Armstrong \& Taylor, 2014, p. 177), which influences 'the extent to which an individual's abilities match the requirements of the job' (Kozlowski, 2012, p. 379).

All the above discussions clearly affirm that job satisfaction influences both the moral state and the behavior of employees. With respect to different situations and preferences, employees either draw pleasure out of their job position or they are displeased. Various studies in different sectors (Mathieu, Fabi, Lacoursière, \& Raymond, 2012; Olawale, Folusollesanmi, \& Olarewaju, 2016; Wen, Muthuveloo, \& Teoh, 2018) have provided evidence that intention to quit is linked with job satisfaction. It confirms the claim that job dissatisfaction is among the different reasons among employees to quit their current job position.

Despite several studies on job satisfaction in multinational companies (eg Andreassi, Lawter, Brockerhoff, \& Rutigliano, 2014), little has been done in the context of Mauritius. Thus, this study would contribute further to existing literature to understand two factors under the lens of this study, which affect job satisfaction in the Mauritian context.

\section{Performing duties outside job description}

According to the Pay Research Bureau (PRB) Report 2008 of the Prime Minister's Office of Mauritius, the holder of a post has 'to perform any other cognate duties' (Pay Research Bureau Report, 2008, para. 10.4) and the term 'cognate duties' has never been defined. With increase in misinterpretation and lack of specific explanation of the terms, the ministry recommended that in every case the terms 'cognate duties' show up in schemes of service, they should be reinstated as:

[O]ther duties directly related to the main duties listed above or related to the delivery of the output and results expected from incumbents in the roles ascribed to them according to their postings. (Pay Research Bureau Report 2008, para. 10.8)

It is deduced that a job description enables employees to get acquainted with a job (Brannick, Levine, \& Morgeson, 2007) but when they are faced with duties, which have not been mentioned in the job description, they begin to doubt whether they are made for these positions (Lane, 2005; Robbins \& Judge, 2013) and their familiarity with the job begins to decline (Brannick et al., 2007).

Robbins (1996) explains that a job description provides a formal relationship between an employee and the organisation. He also added that a job description is a guide for the incumbent 
to follow and to enable the employee to perform duties within the norms of the organisation (Statt, 2004). A job description thus provides 'a list of duties that a person should do, the responsibilities that need to be undertaken' (Dessler, 2013, p. 105) and what the organisation expects from the employee (Marsden, Caffrey, \& McCaffery, 2013). It should not be mistaken for job specification, which describes what criteria a person should meet and what the job asks for (Sparrow, 2000), and these criteria help managers to conceptualise the scope of duties suitable for the employee (Schell \& Kieshauer, 1987). Sanchez and Levine (2009) postulated that a job description represents the minimum activities that the employee is committed to perform. This means that an employee may be expected to perform duties that are not included in the job description (National Labor Relations Board, 2008) because each job cannot be finitely defined (Itika, 2011). However, 'the duties should be in line with the key responsibilities expected from the incumbent' (Royer, 2009) and 'should not overlap' (Lane, 2005, p. 368) or conflict (Armstrong, 2012; Robbins, 1996; Robbins \& Judge, 2013) with the main functions and obligations.

Quah and Campbell (1994) argued that many individuals have the tendency to be intolerant towards performing duties that they were not aware of (Cordes \& Dougherty, 1993; Lepine, Zhang, Crawford, \& Rich, 2016). The absence of clear and specific information of the job (Quah \& Campbell, 1994) increases the inaccuracy of job descriptions and employees are forced to perform duties outside the job description (El-Hajji, 2011). Incumbents thus fail to understand the real nature of the duties because they find their expectations more and more complex to understand (Armstrong, 2012; Lane, 2005; Robbins \& Judge, 2013).

\section{Limited career prospect}

Monis and Sreedhara (2011) acknowledged that one of the prominent causes of employees leaving multinational companies (MNCs) is because of the lack of career opportunities. They also recognised that literature on the relationship between career prospects and job satisfaction in MNCs is quite limited. In a study on job satisfaction among youths in Mauritius, Kisto (2016) provided evidence that among the various reasons for them leaving employment includes lack of career advancement. The study of Kisto (2016) revealed that lack of opportunities for advancement is a determinant of job satisfaction because this variable affects youths both mentally and emotionally contributing to their dissatisfaction with their current job positions. As part of Locke's (1976) definition of job satisfaction and the conclusive remarks of Kisto (2016), it can be deduced that offering employees with appropriate career opportunities would make job experience 'pleasurable'. Advancement in the organisation by many is regarded as a self-actualizing factor. Having promotion opportunities would allow employees to achieve 'self-fulfillment and accomplishment through personal growth' (Maslow, 1943) and not able to fulfill this need would cause the employee to lose interest in the current job (Iles \& Judge, 2004).
Employees usually opt for a job position in which the probabilities of getting promoted or the chances of acquiring professional growths are high (Okurame, 2012). Schömann and Hilbert (1998) hypothesized that fixed-term contracts contribute to poor career prospects and McGinnity and Mertens (2002) further discussed that temporary employment also adds to poor career prospects. In some situations, employees choose to even leave the company because of lack of promotion (Shahi, 2012). Following a publication in 2012, Deloitte Consulting LLP mentioned that an appropriate job leveling should provide logical career paths. The report further pointed out that job leveling will be easier when job titles and job competencies are aligned (Deloitte Consulting LLP, 2015). Similarly, division of levels within an organisation will create increasing circumstances for career growth (Spencer \& Muchnick, 2015), which deliberately explains why currently some companies have limited career prospects.

\section{Relationship between performing duties outside job description, limited career prospect and job satisfaction}

Belias, Koustelios, Sdrolias and Aspridis (2014) discussed that employees are dissatisfied when they do not have a clear understanding of their jobs. In a research in the public sector employment, Addae, Parboteeah and Velinor (2008) posited that employees do not perform effectively as expected when they do not have clear information on their roles. This notion was also shared by Um and Harrison (1998) when they provided evidence that decrease in the level of job satisfaction is directly linked with employees who do not perform duties as described in their job descriptions.

Several researches (Ali, Raheem, Nawaz, \& Imamuddin, 2014; Monis \& Sreedhara, 2011; Rast \& Tourani, 2012) have determined that a relationship exists between career prospects and job satisfaction. Belias et al. (2014) also identified that employees are dissatisfied because they are not given the chance to have a better career prospect to prove their competences. In a study on job satisfaction in Slovakia, Hajdukova, Klementova and Klementova (2015) brought up the notion of 'self-realisation', a determinant of job satisfaction linked with career prospect. Hajdukova et al. (2015) explain that 'self-realisation' is a stimulus that allows individuals to make the necessary efforts and use their skills and intellects to accomplish their desires and needs to reap the associated benefits. It is thus understood that, with the lack of career prospects, people would not be able to obtain the power to fulfill his or her ambitions.

\section{Research design Research approach}

A quantitative approach was used for this study and selfadministered questionnaires were used to achieve the research objectives. 


\section{Research method}

\section{Participants, sampling and procedures}

The participants are employees in a multinational company dealing with customers worldwide and operating on a $24 / 7$ basis. To obtain a viable sample $(n=132)$ (See Table 1$)$, random sampling (Thompson, 2012) was used in this study. Questionnaires were distributed and collected via personal visits using hard-copies. The data was transcribed and processed through Statistical Package for the Social Sciences (SPSS) version 22 (2013).

\section{Measuring instruments}

Viewpoints and conclusions were extracted from literature review and specific questions were formulated. The questionnaire was divided into four sections with three sections dedicated to statements pertaining to job description, career prospect and job satisfaction, respectively. The last section was devoted to demographics to describe the characteristics of the sample such as marital status, age and tenure. Under job description, six statements were formulated to extract information on situations and issues related to how far tasks match employees' respective job description. The statements were adapted from the Minnesota Job Description Questionnaire (Weiss, Dawis, England, \& Lofquist, 1967). Under career prospect, seven statements were devised to obtain facts about the importance of career plans and development in the life of employees. For the purpose of this section, the items were reproduced from the Spector's Job Satisfaction Survey (JSS) (Spector, 1985) and the Manual for the Minnesota Satisfaction Questionnaire (MSQ) (Weiss et al., 1967). Lastly, 10 items were developed under job satisfaction to pull out occurrences related to job description. The items were adapted from Spector's Job Satisfaction Survey (Spector, $1985,1994)$. The items were aggregated under each construct (job description, career prospect and job satisfaction) using SPSS version 22 (2013).

A 3-point Likert scale (Jacoby \& Mattel, 1971) was used to offer respondents a choice of three responses to express their perceptions on how much they agree or disagree with each

TABLE 1: Characteristics of respondents.

\begin{tabular}{lcc}
\hline $\begin{array}{l}\text { Characteristics of } \\
\text { sample }\end{array}$ & $\begin{array}{c}\text { Number of } \\
\text { respondents }\end{array}$ & $\begin{array}{c}\text { Percentage of } \\
\text { respondents }\end{array}$ \\
\hline $\begin{array}{l}\text { Marital status } \\
\text { Married }\end{array}$ & 94 & 71.2 \\
Single & 38 & 28.8 \\
Age & 3 & \\
$<20$ years & 86 & 2.3 \\
$20-29$ years & 40 & 65.2 \\
$30-39$ years & 3 & 30.3 \\
$40-49$ years & & 2.3 \\
Tenure & 78 & \\
$1-4$ years & 45 & 59.1 \\
$5-10$ years & 6 & 34.1 \\
$11-15$ years & 3 & 4.5 \\
$16-20$ years & & 2.3 \\
\hline
\end{tabular}

$N=132$. statement with a neutral point being 'neutral'. A score was allocated to each choice namely Disagree $=1$; Neutral $=2$ and Agree $=3$.

\section{Validity and reliability}

Pilot testing allowed the researcher to address any issues with the questionnaire that was developed for this study. One manager, two team leaders and seven employees were randomly chosen and were requested to fill in the questionnaire to point out any typographical mistakes that could have slipped; secondly, to ensure that the items were clear and well-designed and finally to have an insight on the best average time required when filling in the questionnaire. On the other hand, to increase reliability, test-retest procedure (Lavrakas, 2008) was undertaken among 20 employees a few days after addressing issues identified during pilot testing to increase consistency of the survey questionnaire. The measuring instrument yielded a Cronbach's Alpha value $=0.81$ for the $n=132$ sample indicating good internal reliability.

\section{Research procedure}

Permission was asked from the participating company and ethical clearance was obtained after the company was provided with a list of ethical measures. After the assurance that participants would voluntarily complete the questionnaires, hard-copies of questionnaires were distributed along with a covering letter explaining the aim, purpose and objectives of the research along with all the ethical measures regarding confidentiality and anonymity. To obtain informed consent, participants were also explained how the data would be used and who would use them. Participants were given a week to complete the questionnaires and they were informed that they could quit from the process at any time without any punitive action.

\section{Statistical analysis}

To process the collected data, the SPSS version 22 (2013) software was used. Cross-sectional research was carried out to determine the impact between job description, career prospect and job satisfaction within a multinational company in Mauritius. Pearson's product-moment correlation and regression were conducted to test the hypotheses under study.

\section{Results \\ Correlational statistics}

Job description $(r=-0.569, \rho=0.000)$ is significant and its coefficient is negative indicating that the greater the proportion of performing duties outside the job description, the lower the job satisfaction. Null hypothesis is rejected implying that job description negatively impacts job satisfaction in the Mauritian context. On the other hand, there is a strong negative relationship between career prospect $(r=-0.788, \rho=0.000)$ and job satisfaction, indicating that the greater the chances of career prospect being limited, 
the lower the job satisfaction levels. Null hypothesis is also rejected showing evidence that career prospect negatively impacts job satisfaction in the Mauritian context.

\section{Regression analysis}

The total variability $\left(R^{2}=0.324\right)$ shows that $32.4 \%$ of all variances indicate that job description (Table 3 ) is a good predictor of job satisfaction and adjusted $R^{2}$ is indicative of medium effect size, according to Cohen's (1988) effect size classification. Table 4 shows that the regression analysis is statistically significant, $F(1,130)=62.279, \rho=0.000$, indicating that the construct predicts the dependent variable, job satisfaction. A moderate negative linear regression ( $\beta=-0.569, \rho=0.000)$ can, therefore, be established that job description is predictor of low job satisfaction, $F(1,130)=$ 62.279, $\rho=0.000$, and performing duties outside the job description accounts for $31.9 \%$ of the explained variability in the level of job satisfaction.

In Table 5, the total variability, $\left(R^{2}=0.621\right)$ shows that $62.1 \%$ of all variances indicate that career prospect is a good predictor of job satisfaction and adjusted $R^{2}$ is indicative of

TABLE 2: Pearson's Product-moment correlation of Job Description, Career Prospect and Job Satisfaction.

\begin{tabular}{lccc}
\hline Variable & \multicolumn{3}{c}{ Correlations } \\
\cline { 2 - 4 } & Job description & Career prospect & Job satisfaction \\
\hline Job description & & & \\
Pearson correlation & 1.000 & $0.308^{*}$ & $0.569^{*}$ \\
Sig. (2-talied) & - & 0.000 & 0.000 \\
$N$ & 132 & 132 & 132 \\
Career prospect & & & \\
Pearson correlation & $0.308^{*}$ & 1.000 & $0.788^{*}$ \\
Sig. (2-talied) & 0.000 & - & 0.000 \\
$N$ & 132 & 132 & 132 \\
Job satisfaction & & & \\
Pearson correlation & $-0.56^{*}$ & $-0.788^{*}$ & 1.000 \\
Sig. (2-talied) & 0.000 & 0.000 & - \\
$N$ & 132 & 132 & 132 \\
\hline
\end{tabular}

*, Correlation is significant at the 0.01 level (2-tailed).

TABLE 3: Summary of regression of job description and job satisfaction.

\begin{tabular}{lcccc}
\hline Model & $\boldsymbol{R}$ & $\boldsymbol{R}$ square & Adjusted $\boldsymbol{R}$ square & Std. error of the estimate \\
\hline 1 & $0.569 \dagger$ & 0.324 & 0.319 & 1.81853
\end{tabular}

Std., standard.

$\dagger$, Predictors: (constant), Job description.

TABLE 4: Analysis of variance (ANOVA) † summary of regression of job description and job satisfaction.

\begin{tabular}{lccccc}
\hline Model & Sum of squares & df & Mean Square & $\boldsymbol{F}$ & Sig. \\
\hline 1 Regression & 205.960 & 1 & 205.960 & 62.279 & $0.000 \dagger$ \\
2 Residual & 429.919 & 130 & 3.307 & - & - \\
\hline Total & $\mathbf{6 3 5 . 8 7 9}$ & $\mathbf{1 3 1}$ & - & - & - \\
\hline
\end{tabular}

Sig., significance; df, degrees of freedom.

$\dagger$, Predictors: (constant), Job description.

TABLE 5: Summary of regression of career prospect and job satisfaction.

\begin{tabular}{lcccc}
\hline Model & $\boldsymbol{R}$ & $\boldsymbol{R}$ square & Adjusted $\boldsymbol{R}$ square & Std. error of the estimate \\
\hline 1 & $0.788 \dagger$ & 0.621 & 0.618 & 1.36152 \\
\hline
\end{tabular}

Std., standard.

$\dagger$, Predictors: (constant), Career prospect. large effect size, as per Cohen's (1988) effect size classification. The regression analysis is statistically significant, $F(1,130)=$ 213.026, $\rho=0.000$, showing that the model statistically predicts the dependent variable, job satisfaction (Table 6). A strong negative linear regression $(\beta=-0.788, \rho=0.000)$ can, therefore, be established that career prospect significantly predicts low job satisfaction, $F(1,130)=213.026, \rho=0.000$, and limited career prospect accounts for $61.8 \%$ of the explained variability in the level of job satisfaction.

\section{Discussion Outline of the results}

Product-moment correlation analysis showed that there is a significant association between job description, career prospect and job satisfaction $(p=0.000)$. The result also revealed that there is a negative correlation between job description and job satisfaction, and a negative correlation between career prospect and job satisfaction. The outcomes prove the relevance and importance of both predictor variables at the workplace.

The results demonstrated that employees do feel that they perform duties outside their job descriptions within the company and respondents show moderate resentment towards the issue leading to low satisfaction. These findings are consistent with similar arguments of Quah and Campbell (1994) and Belias et al. (2014), where unclear information of the job increases the inaccuracy of job description forcing individuals to perform duties outside their job description (El-Hajji, 2011). Being uncertain of their roles, employees more likely perform poorly (Addae et al., 2008). Although there is a lack of research to understand this relationship, the outcomes of this study do provide evidence that job description impacts on job satisfaction. Consequently, the impact of this variable on job satisfaction being moderate explains that the level of job satisfaction would decrease whenever clarity of job descriptions is low. It is because employees do not tolerate any mismatch between what they are doing and what they actually should be doing (Cordes \& Dougherty, 1993; Lepine et al., 2016).

On the other hand, based on the findings regarding limited career prospects, incumbents show low satisfaction meaning that career prospects highly influence job satisfaction among individuals. It means that it is important for a company to have proper career opportunities, development or plans. It can also be concluded that there is a relationship, but the relationship does not establish that the levels of these opportunities are low. The findings are consistent with similar studies, which have reported that limited career opportunities

TABLE 6: Analysis of variance (ANOVA) $\dagger$ summary of regression of career prospect and job satisfaction.

\begin{tabular}{lccccc}
\hline Model & Sum of squares & df & Mean square & $\boldsymbol{F}$ & Sig. \\
\hline 1 Regression & 394.893 & 1 & 394.893 & 213.026 & $0.000 \mathrm{~b}$ \\
2 Residual & 240.985 & 130 & 1.854 & - & - \\
\hline Total & $\mathbf{6 3 5 . 8 7 9}$ & $\mathbf{1 3 1}$ & - & - & - \\
\hline
\end{tabular}

Sig., significance; $\mathrm{df}$, degrees of freedom. 
decrease job satisfaction. The outcomes corroborate with the arguments of Ali et al. (2014), Monis and Sreedhara (2011) and Rast and Tourani (2012) that career prospects are determinant of job satisfaction. The study reveals that whenever the chances of career opportunities are low, the higher is the impact on job satisfaction among employees (Kisto, 2016), exhibiting low job satisfaction.

\section{Practical implications}

Research that relates job description and career prospect with job satisfaction in the Mauritian context is almost nonexistent. To tighten this restriction, these dimensions have not been highly explored in a multinational company in Mauritius. The findings of this study, thus, contribute to limited knowledge regarding the relationship of job description and career prospect with job satisfaction and to a broad body of literature on job satisfaction. The research also adds to existing body of knowledge and discipline in a developing country. The findings of this study confirm that when individuals perform duties outside the job description and are provided with limited career prospects, job satisfaction would be negatively affected. The results also bring human resource practitioners, managers and team leaders into the light that the impact of both predictors range from moderate to high which should raise their concern and understand how important these variables are.

\section{Limitations and recommendations}

The first limitation pertains to the study being undertaken in one company only and the sample that was taken might not be a representative of all the other multinational companies in Mauritius. Secondly, a larger sample from different multinational companies in Mauritius would provide a better understanding of the relationships between the variables. It is because a bigger sample size would have provided more evidence on whether individuals do perform duties outside their job descriptions and whether they do have limited career prospect in MNCs in Mauritius. The relationship between the variables with job satisfaction could further be established. Thirdly, it is recommended that demographics be linked with the relationships and impacts of the variables under study. The research could unveil deeper causation of low job satisfaction. Fourthly, demographics cross-linked with the predictors and their impact on job satisfaction would enhance understanding of the existence of cultural bias.

\section{Conclusion}

The aim was to determine the relationships between job description, career prospect and job satisfaction in a Business Process Outsourcing (BPO) company in Mauritius. The results showed that the questionnaire used for this study to collect data was valid and reliable. Correlational analysis yielded negative association between job description, career prospect and job satisfaction. The analysis indicates that whenever the level of the predictor variable would increase, the lower would be the job satisfaction. This outcome explains that whenever an employee performs more duties that are outside the job description, the lower will be his or her satisfaction towards the job. Similarly, whenever an employee becomes aware of career prospect being limited, job satisfaction decreases. To accentuate on the impact of the predictor variables on job satisfaction, regression analysis further pointed that the lower the job satisfaction, the higher is the impact on the employees. The hypotheses have been tested statistically and the objectives of the study have been met that confirmed the claims, arguments and findings in literature.

\section{Acknowledgements}

The author sincerely thanks the managing director who agreed to the administration of the questionnaires and all the participants who agreed to fill them. He specially thanks his wife for encouraging him throughout this research.

\section{Competing interests}

The author declares that he has no financial or personal relationships that may have inappropriately influenced him in writing this article.

\section{Authors' contributions}

K.S.R. undertook all the stages of this research without any assistance, ranging from the formulation of the methodology, data collection, statistical analysis and interpretation and writing up of the literature review.

\section{Ethical considerations}

A letter of authorisation was sought in writing from the Multinational Company (MNC). A written statement was provided to the company regarding anonymity of participants. No information was asked from them that could identify the company or the people. The data have never been shared and have been used solely for the purpose of this study. The data have neither been made available to the company nor to any other parties.

\section{Funding information}

This research received no specific grant from any funding agency in the public, commercial or not-for-profit sectors.

\section{Data availability statement}

Data sharing is not applicable to this article as no new data were created or analysed in this study.

\section{Disclaimer}

The views expressed in this article are the author's own and not an official position of the institution.

\section{References}

Addae, H.M., Parboteeah, K.P., \& Velinor, N. (2008). Role stressors and organisational commitment: Public sector employment in St. Lucia. International Journal of Manpower, 26(6), 567-582. https://doi.org/10.1108/01437720810904220 
Ali, W.U., Raheem, A.R., Nawaz, A., \& Imamuddin, K. (2014). Impact of stress on job performance: An empirical study of the employees of private sector universities of Karachi, Pakistan. Research Journal of Management Sciences, 3(7), 14-17.

Andreassi, J.K., Lawter, L., Brockerhoff, M., \& Rutigliano, P.J. (2014). Cultural impact of human resource practices on job satisfaction: A global study across 48 countries. Cross Cultural Management: An International Journal, 21(1), 55-77. https://doi. org/10.1108/CCM-05-2012-0044

Armstrong, M. (2006). A handbook of human resource management (10th edn.). Cambridge, UK: Cambridge University Press.

Armstrong, M. (2012). Armstrong's handbook of human resource management (12th edn.). Hampshire, UK: Ashford Color Press.

Armstrong, M., \& Taylor, S. (2014). Armstrong's handbook of human resource management (13th edn.). Hampshire, UK: Ashford Colour Press.

Belias, D., Koustelios, A., Sdrolias, L., \& Aspridis, G. (2014). Job satisfaction, role conflict and autonomy of employees in the Greek banking organisation. ProcediaSocial and Behavioral Sciences, 175(2015), 324-333. https://doi.org/10.1016/j. Social and Behavioral
sbspro.2015.01.1207

Bhojak, Y., \& Shakdwipee, P. (2014). A study of employee satisfaction with special reference to "manufacturing industries" International Journal of Modern Communication Technologies \& Research, 2(8), 22-28.

Brannick, M.T., Levine, E.L., \& Morgeson, F.P. (2007). Job and work analysis: Methods, research and applications for human resource management (2nd ed). Thousand Oaks, CA: Sage.

Cohen, J. (1988). Statistical power analysis for the behavioral sciences (2nd edn.). Hillsdale, NJ: Lawrence Earlbaum Associates.

Cordes, C., \& Dougherty, T. (1993). A review and an integration of research on job burnout. Academy of Management Review, 18(4), 621-656. https://doi.org/ $10.2307 / 258593$

Deloitte Consulting LLP. (2015). Job architecture: Laying the building blocks of effective human capital management. Deloitte Development LLC. Retrieved from http:// www2.deloitte.com/content/dam/Deloitte/us/Documents/human-capital/us cons-job-architecture-041315.pdf.

Dessler, G. (2013). Human resource, management (13th edn.). New Jersey, USA: Prentice Hall.

El-Hajji, M.A. (2011). Some recent trends in writing job description for the purpose of job evaluation: A reflective view. American International Journal of Contemporary Research, 1(3), 6-14.

Hajdukova, A., Klementova, J., \& Klementova, J. (2015). The job satisfaction as a regulator of the working behaviour. Procedia - Social and Behavioral Sciences, 190(2015), 471-476. https://doi.org/10.1016/j.sbspro.2015.05.028

lles, R., \& Judge, T.A. (2004). An experience-sampling measure of job satisfaction and its relationships with affectivity, mood at work, job beliefs, and general job satisfaction. European Journal of Work and Organisational Psychology, 13(3), 367-389. https://doi.org/10.1080/13594320444000137

Itika, J.S., (2011). Fundamentals of human resources management: Emerging experiences from Africa. Leiden: African Studies Centre.

Jacoby, J., \& Mattel, M.S. (1971). Three-point Likert scales are good enough. Journal of Marketing Research, 8(4), 495-500. https://doi.org/10.2307/3150242

Kisto, M. (2016). Determinants of youth job satisfaction in Mauritius. International Journal of Scientific and Technology Research, 5(12), 129-132.

Kozlowski, W.J. (2012). The Oxford handbook of organisational psychology (Vol. 1). New York: Oxford University Press.

Lane, L.L. (2005). By all means communicate: An overview of basic speech communication (2nd edn.). Upper Saddle River, NJ: Prentice Hall.

Lavrakas, P.J. (2008). Encyclopedia of survey research methods. Thousand Oaks, CA: Sage.

Lepine, M.A., Zhang, T., Crawford, E.R., \& Rich, B.L. (2016). Turning their pain to gain: Charismatic leader influence on follower stress appraisal and job performance.
Academy of Management Journal, 59(3), 1036-1059. https://doi.org/10.5465/ Academy of Mand
amj.2013.0778

Locke, E.A. (1976). The nature and causes of job satisfaction. In M.D. Dunnette (edn.) Handbook of industrial and organisational psychology (pp. 1297-1349). Chicago, IL: Rand McNally.

Lumley, E.J., Coetzee, M.R., Tladinyane, R., \& Ferreira, N. (2011). Exploring the job satisfaction and organisational commitment of employees in the information technology environment. Southern African Business Review, 15(1), 100-118.

Marsden, P., Caffrey, M., \& McCaffery, J. (2013). Human resources management assessment approach. Washington, DC: USAID.

Maslow, A.H. (1943). A theory of human motivation. Psychological Review, 50(4), 370-396.

Mathieu, C., Fabi, B., Lacoursière, R., \& Raymond, L. (2012). The role of supervisory behavior, job satisfaction and organisational commitment on employee turnover. Journal of Management \& Organisation, 22(1), 113-129. https://doi.org/10.1017/ jmo.2015.25

McGinnity, F., \& Mertens, A. (2002, February). Fixed-term contracts in east and west Germany: Low wages, poor prospects? Paper presented at the GSOEP2002 International Conference, Berlin, Germany.
Monis, H., \& Sreedhara, T.N. (2011). Employee satisfaction with career development practices: A comparative study of Indian and foreign MNC BPO Firms. Journal of practices: A comparative study of Indian
Arts Science \& Commerce, 2(1), 110-122.

Millar, M.G., \& Tesser, A. (1989). The effects of affective-cognitive consistency and thought on the attitude-behavior relation. Journal of Experimental Socia Psychology, 25(2), 189-202. https://doi.org/10.1016/0022-1031(89)90012-7

Mullins, L.J. (2002). Management and organisational behaviour (6th edn.). Upper Saddle River, NJ: Prentice Hall.

National Labor Relations Board. (2008). Decisions and orders of the national labor relations board. Washington, DC: US Government Printing Service.

Okurame, D. (2012). Impact of career growth prospects and formal mentoring on organisational citizenship behaviour. Leadership and Organisation Development Journal, 33(1), 66-85. https://doi.org/10.1108/01437731211193124

Olawale, A.R., Folusollesanmi, J., \& Olarewaju, A.A. (2016). Job satisfaction, turnove intention and organisational commitment. BVIMSR's Journal of Management Research, 8(2), 102-114.

Pay Research Bureau Report. (2008). General background and related issues and conditions of service: Review of schemes of service and qualifications. Retrieved from Library/Circulars\%202008\%20-\%20Library/Circular\%20Letters\%202008/CL35.pdf.

Quah, J., \& Campbell, K.M. (1994). Role conflict and role ambiguity as factors in work stress among managers in Singapore: Some moderator variables. Research and Practice in Human Resource Management, 2(1), 21-33.

Rast, S., \& Tourani, A. (2012). Evaluation of employee's job satisfaction and role of gender difference: Am Empirical Study at Airline Industry in Iran. International Journal of Business and Social Science, 3(7), 91-100.

Robbins, S.P. (1998). Organisational behaviour: Concepts, controversies, applications (7th edn.). Upper Saddle River, NJ: Prentice Hall.

Robbins, S.P., \& Judge, T.A. (2013). Organisational behavior (15th edn.). Upper Saddle River, NJ: Prentice Hall.

Royer, K.P. (2009). Job descriptions and job analyses in practice: How research and application differ. (Unpublished doctoral dissertation). DePaul University, Chicago, application differ.
United States.

Sanchez, J.I., \& Levine, E.L. (2009). What is (or should be) the difference between competency modelling and traditional job analysis? Human Resource Management Review, 19(1), 53-63. https://doi.org/10.1016/j.hrmr.2008.10.002

Schell, B.A.B., \& Kieshauer, M.L. (1987). Beyond the job description: Managing for performance. The American Journal of Occupational Therapy, 41(5), 305-309. https://doi.org/10.5014/ajot.41.5.305

Schömann, K., \& Hilbert, C. (1998). The youth labour market in Germany - A new target group for German labour market policies? Vierteljahrshefte zur Wirtschaftsforschung, 67(4), 272-285.

Shahi, T.A. (2012). Factors affecting job satisfaction, motivation and turnover rate of medical promotion officer (MPO) in pharmaceutical industry: A study based in Khulna city. Asian Business Review, 1(1), 126-131.

Sparrow, P. (2000). New employee behaviours, work designs and forms of work organisation: What is in store for future of work? Journal of Managerial Psychology, 15(3), 202-218. https://doi.org/10.1108/02683940010320561

Spector, P.E. (1985). Measurement of human service staff satisfaction: Development of the job satisfaction survey. American Journal of Community Psychology, 13(6) 693-713. https://doi.org/10.1007/BF00929796

Spector, P.E. (1994). Job satisfaction survey. Tampa, FL: University of South Florida.

Spencer, J., \& Muchnick, M. (2015). Should we undo the flat organisation: Accommodating needy millennial generation worker. European Journal of Contemporary Economics and Management, 2(2), 14-28. https://doi.org/ 10.19044/elp.v2no2a2

Statistics Mauritius. (2018). Labour force, employment and unemployment-year 2018 [PDF File]. Retrieved from http://statsmauritius.govmu.org/English/Publications/ Documents/2019/E11450/LF_Emp_Unemp_Yr18.pdf.

Statt, D. (2004). Psychology and the world of work (2nd edn.). Hampshire, UK: Palgrave MacMillan.

Thompson, S.K. (2012). Sampling. Hoboken, NJ: Wiley.

Um, M., \& Harrison, D.F. (1998). Role stressors, burnout, mediators, and job satisfaction: A stress-strain-outcome model and an empirical test. Social Work Research, 22(2), 100-115. https://doi.org/10.1093/swr/22.2.100

Waqas, A., Bashir, U., Sattar, M.F., Abdullah, H.M., Hussain, I., Ali, M.A., et al. (2014) Factors influencing job satisfaction and its impact on job loyalty. International Journal of Learning \& Development, 4(2), 142-161.

Weiss, D.J., Dawis, R.V., England, G.W., \& Lofquist, L.H. (1967). Minnesota job description questionnaire. Minneapolis, MN: University of Minnesota.

Wen, C.T., Muthuveloo, R., \& Teoh, A.P. (2018). Factors influencing job satisfaction: A perspective of millennials in Malaysia multinational (MNC) companies. Globa Business and Management Research: An International Journal, 10(1), 48-66.

Westover, J.H. (2008). A cross-national analysis of job quality characteristics and perceived job satisfaction in a changing world economy: Implications for public administrators managing a multicultural workforce. International Review of Public Administration, 13(2), 129-144. https://doi.org/10.1080/12294659.2008.10805126 